\title{
PRÁTICA DE CONFECÇÃO DE SILAGEM NO PROJETO DE ASSENTAMENTO BELO HORIZONTE, SÃO DOMINGOS DO ARAGUAIA- PARÁ
}

\author{
Luis Moreira de Araujo Junior ${ }^{1}$; Alzira Gabriela da Silva ${ }^{2}$ \\ ${ }^{1}$ Discente do Curso de Agronomia, Faculdade de Ciências Agrárias de Marabá (FCAM), Universidade Federal do Pará \\ (UFPA), Marabá, Pará. Bolsista PIBEX. E-mail: luisjrmoreira@ hotmail.com. \\ ${ }^{2}$ Zootecnista, Prof. ${ }^{\text {, }}$ M.Sc. FCAM, UFPA. E-mail: alziragabi@ufpa.br.
}

RESUMO: Nos estabelecimentos agrícolas da agricultura familiar, a produção leiteira desempenha importante papel na alimentação e na melhoria socioeconômica das famílias. Porém, os índices de produtividade do sistema são ineficientes devido, principalmente, ao manejo inadequado das pastagens. A confecção de silagem apresenta-se como uma alternativa viável, pois exige tecnologia simples para conservação mediante a fermentação. Os bancos forrageiros de leguminosas como o amendoim forrageiro (Arachis pintoi), feijão guandú (Cajanus cajan), puerária (Pueraria phaseoloides); leucena (Leucaena leucocephala) e cratylia (Cratylia argentea), associados com gramíneas como o milheto (Pennisetum glaucum) e o sorgo (Sorghum bicolor) apresentam qualidade nutricional superior ao das plantas forrageiras tradicionalmente utilizadas nos sistemas pecuários praticados na região e podem ser usadas na produção de silagem, visando suplementar a alimentação animal no período seco. Objetiva-se conduzir esse trabalho para difundir a prática de confecção de silagem, como alternativa sustentável, para posterior adoção na agricultura familiar paraense. Este trabalho será realizado no período compreendido entre o mês de março e dezembro de 2009 no Projeto de Assentamento (P.A.) Belo Horizonte que possui 70 famílias e está localizado no km 30 da BR-153, no município de São Domingos do Araguaia-PA. A abordagem para a difusão dessa prática no P.A. irá se basear nas metodologias de "grupos de aconselhamento técnico" e na construção de inovações em parcerias com agricultores. Para a confecção de silagem serão implantados dois módulos demonstrativos de bancos forrageiros que poderão ser de leguminosas ou gramíneas com as espécies citadas, sugeridas aos agricultores. O solo da área a ser implantado os módulos demonstrativos será preparado de forma convencional, sendo que o plantio será realizado em meados do mês de março em linhas (de $10 \mathrm{~m}$ de comprimento) espaçadas de 0,70 m entre linhas (gramíneas) e 0,40 m a $1 \mathrm{~m}$ entre-linhas (leguminosa), perfazendo uma área total de aproximadamente $200 \mathrm{~m}^{2}$. A adubação de cobertura será realizada 30 dias após a emergência, com $100 \mathrm{~kg}$. ha ${ }^{-1}$ de N sob forma de sulfato de amônio. Nas épocas pré-determinadas após a semeadura, as plantas da área útil de cada módulo serão cortadas manualmente a altura de $5 \mathrm{~cm}$ do solo. $\mathrm{O}$ material colhido será picado em partículas entre 1,0 e 2,0 cm, com um desintegrador estacionário. Após a homogeneização do material picado, este será armazenado em silo de superfície, compactado e vedado com lona, em área perto do curral e preservado do contado de animais. Serão retirada de cada módulo um (01) kg de amostra, que será acondicionada em saco apropriado para realização de pré-secagem, em estufa de ventilação forçada a $65^{\circ} \mathrm{C}$ por 72 horas. Transcorrido 45 dias, a silagem será fornecida aos animais. A avaliação da adoção da prática de confecção de silagem terá como base critérios agronômicos, econômicos e zootécnicos. Por outro lado, os próprios agricultores avaliarão as inovações, com critérios como mão de obra exigida. Espera-se conceber e testar, com a participação de agricultores, estudantes e técnicos, modelos de gestão sustentável da pecuária leiteira através da difusão da prática de confecção de silagem para posterior adoção na agricultura familiar.

PALAVRAS-CHAVE: Ensilagem, bovinocultura, agricultura familiar. 